ESJ Humanities

\title{
The Sea Power of Small States: A Case Study of Sri Lanka
}

\author{
Jeewaka Saman Kumara
}

Department of Political Science, University of Peradeniya, Sri Lanka

Doi: $10.19044 / \mathrm{esj} .2021 . v 17 \mathrm{n} 2 \mathrm{p} 151$

Submitted: 02 December 2020

Accepted: 28 December 2020

Published: 31 January 2021
Copyright 2021 Author(s)

Under Creative Commons BY-NC-ND

4.0 OPEN ACCESS

Cite As:

Kumara S.J. (2021). The Sea Power of Small States: A Case Study of Sri Lanka. European Scientific Journal, ESJ, 17(2), 151. https://doi.org/10.19044/esj.2021.v17n2p151

\section{Abstract}

The geo-strategic location of Sri Lanka in the Indian Ocean, which is a part of global and regional power competition, is close to the key and busy naval routes between the East and the West. Particularly, the marine area of Sri Lanka has critical geopolitical importance due to its location between the Strait of Hormuz and the Strait of Malacca, which are essential transit zones in the world. The marine area of Sri Lanka has gained much attention from the industrial and newly industrial nations due to the living and non-living natural resources contained in the surrounding sea. With this background note, this paper focuses on discussing the sea power dimension of national security, focusing on the case of Sri Lanka, which has been neglected by contemporary academia of small powers' studies. For this purpose, Alfred Thayer Mahan's theory on sea power has been employed to theoretically and practically examine the feasibility of its application for enhancing the sea power of Sri Lanka in the context of changing global order. The research was drawn from a wide range of secondary sources and a descriptive analysis was made. The paper concludes with implications for some realistic policies for enhancing the sea power capacity of Sri Lanka as it allows the free flow of people and goods as well as the projection of naval power of Sri Lanka.

Keywords: Marine area, Sea Power, Close proximity, Small power, Living resource, Non-living resources

\section{Introduction}

The sea power of a state and its use and control of the sea is associated with the strength of navigation, oceanic currents, maritime transportation, 
coastal society, development of ports and port-towns, sea-borne trade and commerce, port-hinterland relations, armed shipping and so on (Mathew, 1990: XI). Throughout human history, civilizations and economies depended on sea-based commerce, production, and naval capacity for their security, growth as well as prosperity. Therefore, the concept of sea power is probably one of the single most important and contested concepts in security study.

In the typologies of small power' sea power, the definition of sea power can be analyzed in both quantitative and qualitative terms. The quantitative definitions of the sea power of small power deal with 'geopolitical factors'. On the other hand, the qualitative definitions focus on the sea power of small power regarding their differing capabilities or patterns of interaction. However, small power' sea power differs based on several features, including greater vulnerability to external powers in terms of maritime significance. Therefore, most small power in the contemporary world have always faced either balancing or bandwagon dilemma, often with lasting consequences for their existence. Sri Lanka (formerly Ceylon), which is situated in the Indian Ocean Region and surrounded by seawater with strategical significance in term of shipping (unarmed and armed), commerce and production for the global power rivalry, is a classic example of such states which fall in the category of small power being vulnerable to the external powers in terms of maritime significance.

Being a small power in the Indian Ocean with strategical significance, Sri Lanka is vulnerable to both regional and extra-regional power competition. With the changing nature of the global power hierarchy in general and those conditions particular to the Indian Ocean, the geo-strategical significance of Sri Lanka has been one of the central concerns in fields of international politics and international relations. Therefore, Sri Lanka, in recent years, has come up with a new geographic identity. Specifically, ongoing debates regarding China's 99-year lease on the Hambantota Port indicates the recognition of the centrality of the new geographic identity of Sri Lanka with regards to maritime strategy. Historically, the maritime area of Sri Lanka has become a more valuable terrestrial line for energy and goods across the Western part to Eastern part of the world because the country is located between the Strait of Hormuz and the Strait of Malacca, which are vital maritime chokepoints in the world.

Given the above considerations, Sri Lanka occupies an exceptionally crucial location in the world. Annually, more than 60,000 ships pass through sea lanes just six to ten nautical miles away from the country, carrying half of all container shipments and two-thirds of the world's oil transport (Wijesinha, 2016). In addition to this, the marine area of Sri Lanka is rich with living and non-living natural resources. Nevertheless, it makes a minimum contribution to the economy of Sri Lanka. However, it is essential to note that being a 
strategically significant small power in the Indian Ocean, Sri Lanka has given less attention to the development of sea power, which is considered a significant element of national power.

The present study's aims to theoretically examine the feasibility of Alfred Thayer Mahan's theory of sea power for enhancing the maritime capacity/autonomy of Sri Lanka in the context of the changing global order. The second objective is to seek the possible management of traditional and non-traditional maritime security challenges of Sri Lanka. Finally, this study also aims to provide a roadmap to the Maritime Direction to establish maritime commercial diplomatic relations with potential nations to enhance the sea power of Sri Lanka.

The research has been drawn from a wide range of secondary sources. The secondary sources involve various book, articles, newspapers, and internet for the present research. This data will be analyzed with the use of standard research tools, including descriptive and analytical methods. Moreover, the research will involve qualitative research methods as well to find out the perspectives, problems, and challenges of the sea power of small powers that are vulnerable to the global power rivalry like Sri Lanka.

\section{A Conceptualization of the Existing Literature}

Power at sea or sea power has a well-documented history. Therefore, in contemporary academia, there is no lack of theory-oriented studies on states' sea power in general. However, there is a lack of theory oriented scholarly works on the sea power of small power in particular. Thus, the current literature on the sea power of states in general and sea power of small power in particular can be analyzed in traditional and non-traditional paradigms.

The traditional paradigm of sea power is a predominant creation of armed naval power. Therefore, the traditional paradigm of sea power does not offer general theories of sea power. Instead, it has focused its attention on the nature of maritime strategy and the purpose of naval warfare (Gray \& Barnett, 1989, p.39). It is obvious that the sea's command is the central theme of the traditional paradigm of sea power (Hunt, 1989, p.110-135). Moreover, the traditional paradigm of sea power deals with the capability to use sea communications for armed and civic purposes such as protection of territorial sea and fishery industry and to refuse such use to the opponents in general. The maritime dominance and supremacy of powerful nations in particular have become another aspect of the traditional paradigm of sea power. In the Cold-War and Post-Cold War era, sea power has been discussed in academia through strategic studies' prism (Grtmond, 2015, p.5). Therefore, during this period, the sea power was mainly focused on the naval forces as instruments of states rather than the sea as a milieu (Grtmond, 2015, p.6). 
The non-traditional paradigm at sea is more than that. As per the nontraditional paradigm, a nation's sea power depends on several interrelated elements, both inside and outside the navy. Non-traditionalists articulated that the actual strength of a navy is heavily dependent upon finance, the capability of central administration, the quality and quantity of real maritime resources, the ships, seamen and officer corps, the maritime infrastructure, and the quality of political and naval decision-making (Harding, 1999, p.121). Moreover, some of the non-traditionalists have argued that sea power is about geography, geopolitics, geostrategy, geo-economics, and geo-culture. And also, sea power is about the state's sea-based capacity to determine or influence events, currents, and developments both at sea and on land (Corbett, 1988, p.67).

In a broader context, the non-traditional paradigm highlights that the sea power of a state is a system characterized not only by the presence of links between its components like military, merchant shipping, fishing and scientific research fleet, etc., but also by the inseparable union with the environment, i.e., the ocean (Gorshkov, 1979, p.1-3). In short, the non-traditional paradigm of sea power deals with armed naval power and the managing, controlling, and absorbing of maritime natural resources, namely food, hydrocarbons, energy and minerals, and defenses connected to the commercial purposes at sea.

It is noteworthy to mention here that there is a shortage of theory oriented scholarly works on the sea power of Sri Lanka. Most of the existing literature has analyzed the maritime security of Sri Lanka by focusing the attention on the superpower rivalry of the Indian Ocean Region in the context of the cold war politics, either balancing or bandwagon. Therefore, the positive and negative parameters on sea power of Sri Lanka have been neglected. It is clear that most scholars have prioritized analyzing the positive and negative impacts of Sri Lanka's geo-political location in the Indian Ocean Region rather than developing theory-oriented scholarly works that can be applied to enhance the sea power of Sri Lanka. This scenario highlights the impact of the colonial legacy and cold war politics (Jayasekera, 1992). In the post-cold war era, the existing literatures on maritime security in Sri Lanka tends to consider issues like maritime piracy, power struggle, port security, illegal fishing, human trafficking, and drug trafficking. Moreover, matters related to managing the sea power of Sri Lanka, namely environmental crime, protection of natural resources, maintaining the economic value of maritime routes and managing the power struggle over the marine area, have received less attention. With the emergence of the triangular balancing power system in the Indian Ocean Region and the domination of China in Sri Lanka's marine area, some academic works investigate its positive and negative impacts on the maritime security of Sri Lanka. 


\section{The Theoretical Background}

Existing literature reveals that nations have employed sea power to safeguard their national interests throughout human history. In the field of contemporary international politics, the concept of sea power, as an intellectual field, usually analyzes the connection between political power, national interests, armed and unarmed shipping, commerce, production, strategic decision-making, and geographical space. This concept also observes strategic prescription based on the relative significance of sea power. International scholars, apart from the two classical western theorists of sea power, Alfred Thayer Mahan and Julian Corbett, have developed different theories of sea power which have become an integral part of the elements of national power and national security. Till stated that sea power can be understood as a means or as an end (Till, 2004, p.4). Among them, 'Theory of Sea Power' a classical work, The Influence of Sea Power Upon History 16601783, done by Alfred Thayer Mahan, a naval scholar and a historian, in 1890 can be applied in analyzing the contemporary significance of sea power not only for superpowers, great powers as well as regional powers in general but also small powers or small power like Sri Lanka in particular. It is essential to mention here that considering sea power as the most important factor in the formation of world domination, A. T. Mahan concluded that 'the one who owns the sea possesses all' (Mahan, 1890, p.11).

Mahan explains how sea power is part of his theoretical analysis, but he has not clearly defined the term 'sea power'. He remarked that it is 'at once an abstraction and a concrete fact'. Moreover, Mahan has not clearly distinguished sea power from ideas of 'command of the sea' and 'sea control' (Gray \& Barnett, 1989, p.33). As per the observation of Antonio Ruy de Almeida Silva, to Alfred T. Mahan, the sea is a great path, open to all, which allows the free flow of people and goods. He points out that the history of sea power shows an enormous influence of maritime transportation on commerce, wealth and power of nations, and, at the same time, reveals how disputes and economic competition involving the sea often culminated in armed conflicts. Furthermore, he stated that 'the control of the sea is and has been a great factor in the world's history' (Silva, 2017, p.238). For Phillip A. Crowl, he sometimes refers to it as the ability of the military power in its naval expression to control the sea; he also uses it concerning a set of commercial maritime activities, access to markets, and the possession of colonies contributing to a nation's wealth and power (Crowl, 1986). In his analysis, Sam J. Tangredi highlighted that sea power can be defined as the sum of the abilities to conduct international maritime business, utilize marine resources, project military force, and exert influence on onshore affairs from the sea through the navy (Tangredi, 2002, p.3-4). 
However, for Mahan, as he has highlighted in the first chapter of his classical work, the principal conditions affecting the sea power of nations may be enumerated as follows: I. Geographical Position; II. Physical Conformation, including, as connected to natural productions and climate; III. Extent of Territory; IV. Number of Population; V. Character of the People; VI. Character of the Government, including the national institutions (Mahan, 1890, p.29). In short, Mahan is convinced that sea power is based on three interlocking factors namely, shipping (unarmed and armed), production, and colonies (Mahan, 1890, p.28, 43). These three interlocking factors incorporate with the six principal conditions that are affecting the sea power of nations.

Mahan examined the sea power in the broadest context in his analysis of six principal conditions of sea power. Going through visible factors, he highlighted that British supremacy of the sea was a key factor that allowed it to challenge its rivals (Till, 1984, p.31). Moreover, Mahan has identified that sea power is a dynamic capacity of states to use the oceans for achieving their national interests. Therefore, he argues that nations seek sea power as 'a great highway' that provides a means of cheap transportation. His fundamental argument is that no nation could be powerful in the world unless it effectively utilized the maritime area. In addition to this, another objective of his argument was to provide long term stability for the capitalist system in the United States of America.

Since sea power is one of the major elements of national power in contemporary international politics, international relations and naval science, Mahan's three interlocking factors, in the contemporary context of neo economic expansionism, and six principal conditions of sea power were valid for analyzing the elements of national power in the late $19^{\text {th }}$ century. In addition, they were also valid for examining the elements of national power in the 21 st century which affects interaction between sea power and globalization.

\section{Implications of Geographic position}

In his analysis of geographical position, Mahan has clearly identified that geographic position's strategic importance is useful not only when the country has access to the main ocean roads or has a long coastline, but also harbors appropriate for building reliable ports. For Mahan, a country's geographical position may not only favor the concentration of its armed forces. It gives a central position further strategic advantage and a good base for hostile operations against its probable enemies (Wescott, 1999, p.23).

The geopolitical position of Sri Lanka as a small power is traditionally significant for the global and regional power rivalry and competition. Sri Lanka is an island of the South Asian sub-continent. It is located centrally in the Indian Ocean and the Southern part of the Asian continent on the world's 
busiest shipping lane and the world's second busiest oil transit chokepoint. Sri Lanka does not have common borders but is separated from India, South Asia's regional power, by the narrow Palk Strait of about 32 kilometers wide. ${ }^{1}$

Figure 1. Geographical Position of Sri Lanka

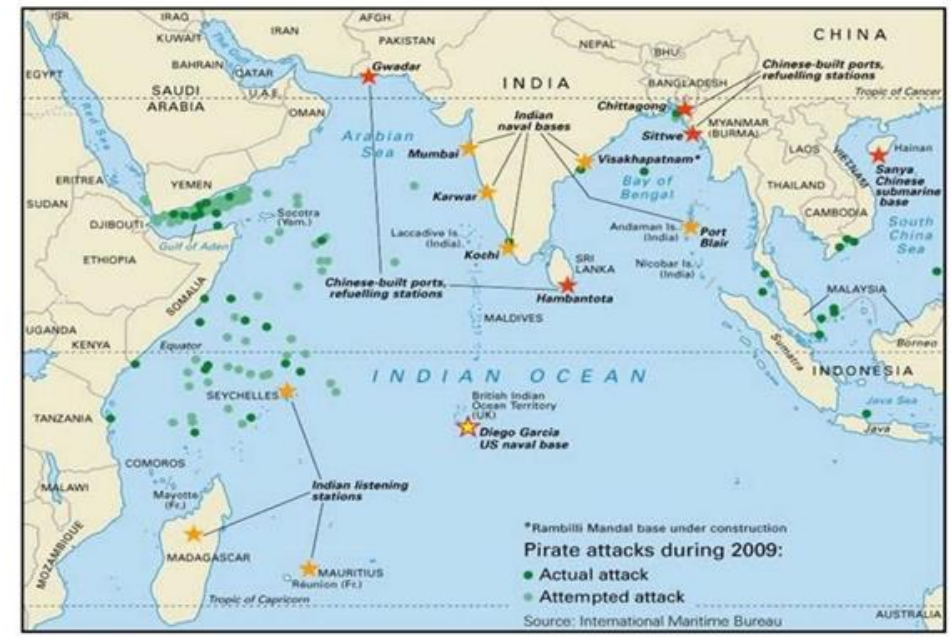

Source: International Maritime Bureau

Moreover, the geographical position of Sri Lanka became the center of the global geostrategic agenda of both superpowers in the Cold War period. Similarly, at a regional level, K.M Parrikar, closely associated with Mr. Nehru, was the first to emphasize an extensive 'Ocean policy' to ensure Indian defense through strategic togetherness between India and the Indian oceanic countries, including Ceylon (Sri Lanka) (Subrahmnyam, 1970, p.139). After the collapse of the Soviet Union and with the emergence of regional actors like India and China, the competition is growing between various parties in terms of the geographical position of Sri Lanka. In addition to the United States of America, China and India, other powers are involved in considering Sri Lanka as a location of interest. Therefore, the geographical position of Sri Lanka undoubtedly makes it a naval hub in the Indian Ocean Region (Carrai, 2019, p.1061-1099).

\section{Physical Conformation}

The physical conformation of a country, the second condition of Mahan's theory of sea power, highlights how the country's physical geography either enriches or prevents its capacity to interact with other nations who are concentrating on the sea (Mahan, 1890, p.35-42). For Mahan, numerous and deep harbors are a source of strength and wealth, and doubly so if they are the

${ }^{1}$ Some border issues between Sri Lanka and India were resolved by signing India-Sri Lanka Maritime Boundary Agreements in 1974. 
outlets of navigable streams, which facilitate in them the concentration of a country's internal trade (Mahan, 1890, p.36). Moreover, some physical conditions which separate a country into two or more parts, depending wholly upon external sources and unique borders, either give birth and strength to sea power, or makes the country powerless (Mahan, 1890, p.40).

Since the ancient period, preserving sea power has become a significant factor for Sri Lanka as it is a small power because of its proximity to India and the main sea route connecting the West and East. Since Sri Lanka is placed at the center of the Indian Ocean with natural ports, it has historically facilitated cross-border trade such as the maritime silk route between China and Europe. The distance from Sri Lanka to the Strait of Homuz and the Strait of Malacca is approximately 2,000 miles, which are the world's most strategic maritime transit points (Singh, 1994, p.84-85). Therefore, the physical setting of Sri Lanka facilitates Sri Lankans to cooperate with other nations in terms of trade and commerce.

Figure 2. Sri Lanka's Position of Strait of Homuz and the Strait of Malacca

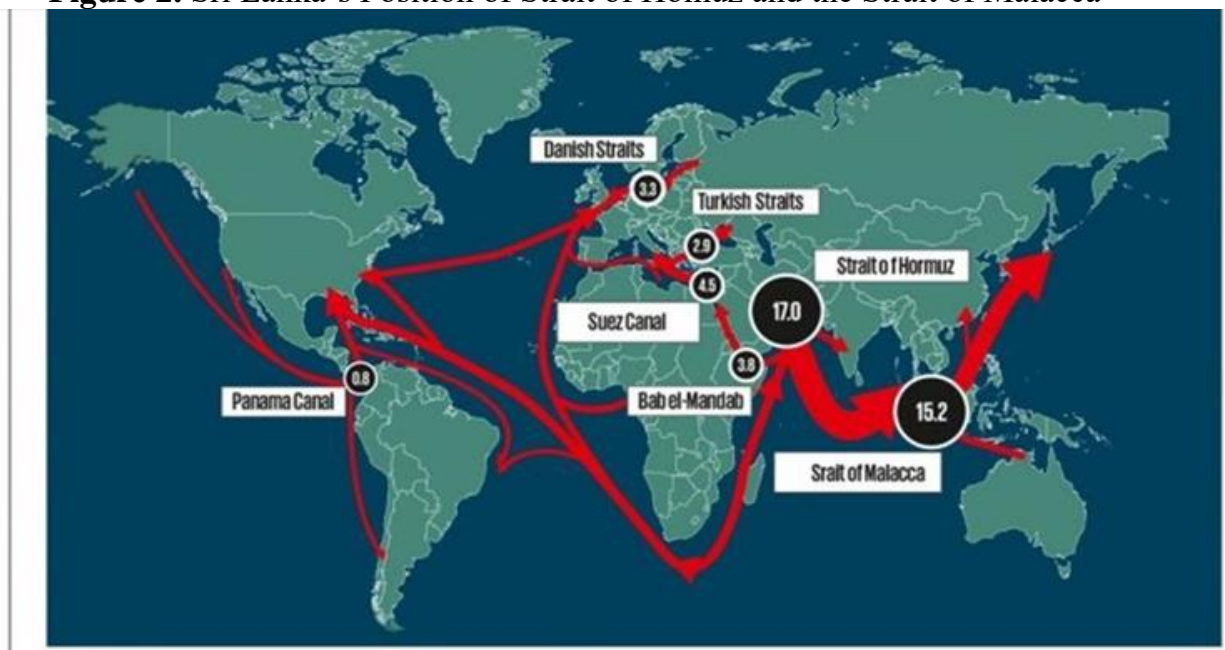

All estimates in million barrels per day.

13-11-2014

AA

Source: Hostage Foundation Research

There are some positive and negative impacts of the physical conformation of Sri Lanka. The Trincomalee port is one of the most strategically important ports in the world (Jayasekera, 1992). In addition to the Portuguese and Dutch, the Trincomalee port was used by the English to effectively control their colonial empire. Furthermore, it was precisely due to its geographical position, in terms of sea power in the Indian Ocean, that the Japanese air force attacked Sri Lanka targeting Colombo and Trincomalee ports in 1942 (The Battle of Ceylon or The Easter Sunday Raid). In short, the British Defense Agreement of 1947, the Maritime Agreement with USSR of 1962, and the Sino-Ceylon commercial maritime agreement in 1963 are some 
examples of the Western and non-Western interest on the physical conformation of Sri Lanka. Therefore, the physical conformation of Sri Lanka's marine area is significant for developing interaction with other nations in terms of shipping, commerce, and production.

Figure 3. Sri Lanka's Position on Major Shipping Routes

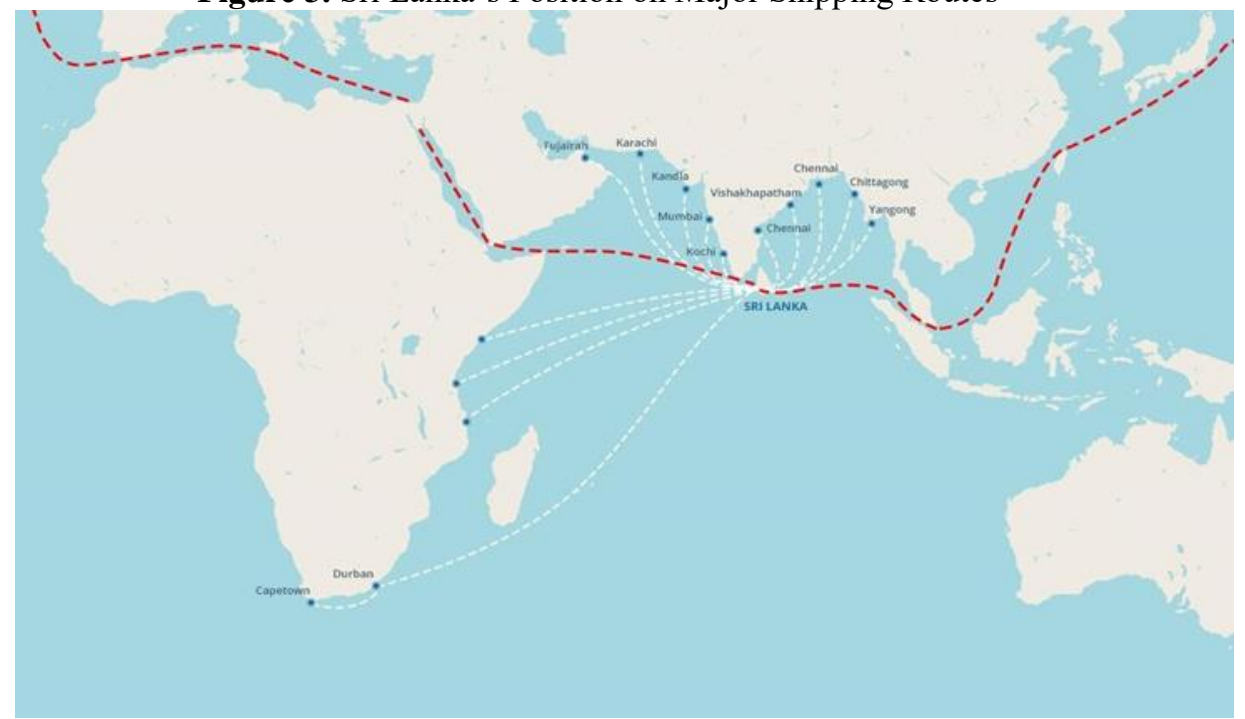

Source: https://www.pslship.com/

\section{Extent of Territory}

In his third condition on sea power, Mahan considered that the extent of territory does not reflect the country's total area. In his analysis, Mahan highlighted that the length of its coastline is relative to the country's size and the strategical importance of harbors (Mahan, 1890, p.43). As per Mahan's conception, even if the country is small in size, the length of the coastline and the harbor's nature determine the country's wellbeing. Further, he has argued that the extent of the sea-coast is a source of strength or weakness according to whether the population is large or small (Mahan, 1890, p.43-44).

Sri Lanka is an island that comprises of a $65,610 \mathrm{~km}^{2}$ land area, and its coastal belt is $1,770 \mathrm{~km}$ (Pernetta, 1993, p.1). Moreover, Sri Lanka is authorized to use the territorial sea up to $12 \mathrm{nms}$, which is a Contiguous Zone up to $24 \mathrm{nms}$ and an exclusive economic zone of up to $200 \mathrm{nms}$. The coastal belt and coastal zone of Sri Lanka consist of natural resources such as land, minerals, surface and ground water, flora, fauna, ilmenite, monazite bearing beach sands, silica sands, miocene limestone, kaolin, china clay, copper, magnetite, peat, etc. Moreover, the fishery sector provides direct employment of up to 150,000 in fishing and to another 100,000 in fishery-related industries, while sustaining nearly 1.25 million persons. In addition, fish contributes to nearly $70 \%$ of the population's animal protein intake and $2.7 \%$ to the national GDP (MFOR, 2002). It has also emerged as an important foreign exchange 
earner, with current annual exports worth Rs.9000 million. It is estimated that around 100,000 fishermen are directly engaged in coastal fishing, including those fishing in lagoons/estuaries. Approximately 500,000 fisherfolk are dependent on coastal fisheries for their livelihood. The majority of the fishermen are low to moderate-income earners with annual incomes between Rs.30, 000 to 63,000 (Joseph, N/Y, p.19). Besides, authority has been established under the provision of act passed by parliament in April 2002 for oil and gas exploration in the national maritime jurisdiction area of Sri Lanka.

Figure 4. Protected Waters of Sri Lanka

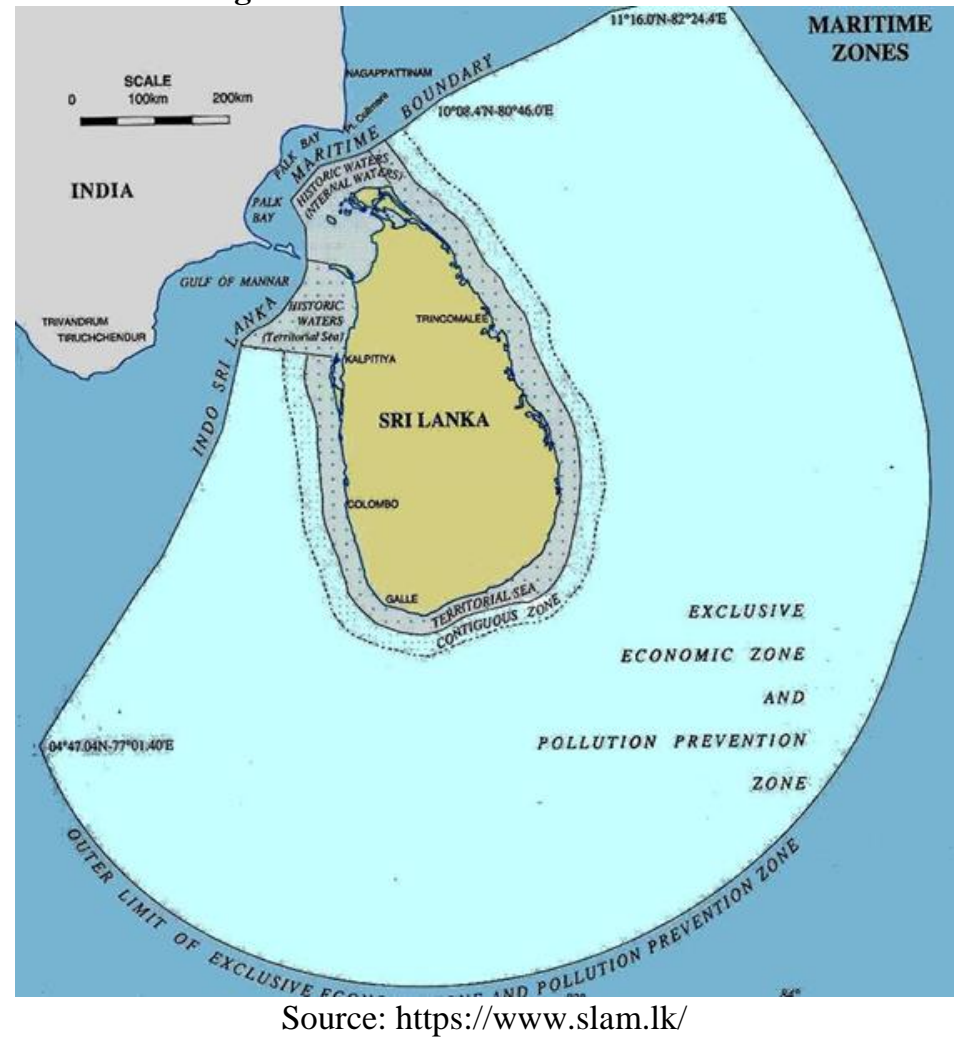

Dealing with the coastline, Sri Lanka has four ports in Colombo, Hambantota, Trincomalee and Galle and two minor harbours at Kankesanthurai and Oluvil. The Colombo harbor, which is among the major harbors in Sri Lanka, is the largest port in Sri Lanka as well as in South Asia (Garver 2001, p.300). The Trincomalee port is considered as the second top natural harbor in the world. Due to its strategic location in the Indian Ocean in terms of armed and unarmed shipping, it serves as an important terminal in Asia. Some of the more economically significant ports of Sri Lanka, namely Galle and Kankesanthurai, were comprehensively damaged during the tsunami in 2004 and Cyclone Nisha in 2008. Nevertheless, Trincomalee, 
Colombo, Hambantota, and Galle are four of the best ports existing in the whole of the South Asian Region in terms of economic and military strategy.

Figure 5. Major Ports of Sri Lanka

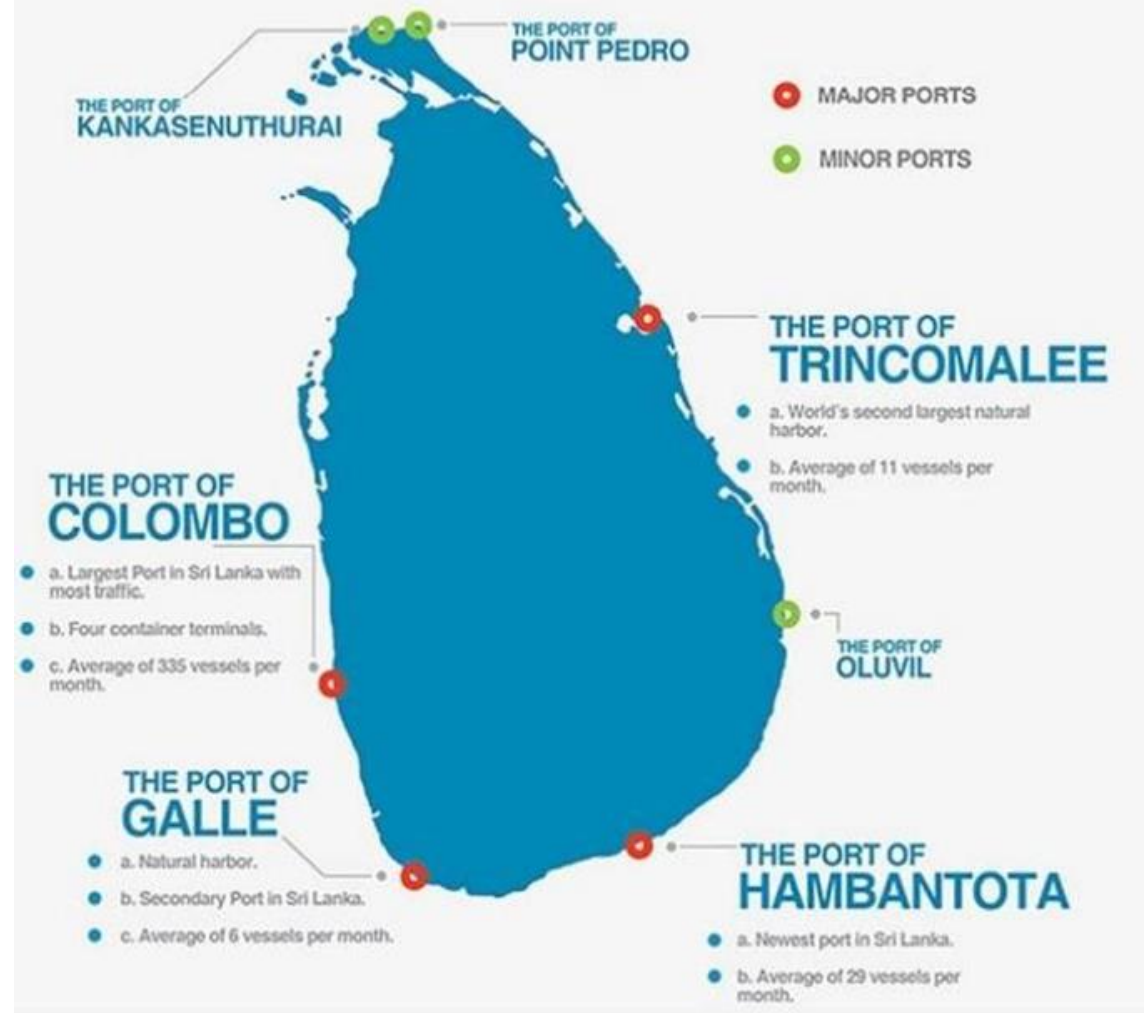

Source: https://www.studyiq.com/

In addition to the Colombo and Trincomalee ports, the Hambantota port, located ten nautical miles off the world's busiest east-west shipping route and one of the controversial ports built by China in the southern part of Sri Lanka, plays a strategic role for the Maritime Silk Road in the Indo-Pacific region. It provides shipbuilding, bunkering, ship repair, and crew change facilities. In comparison to other ports in the South Asian Region, the ports of Sri Lanka are very close to the major maritime routes between the East and the West. Due to its unique physical setting/placement conformation, Sri Lanka has undoubtedly become an attractive trading hub in terms of terminal productivity and the successful handling of mega-ships. Mahan mentioned 'numerous and deep harbors are a source of strength and wealth' (Mahan, 1890, p.36). Thus, the ports of Sri Lanka are very important not only for military purposes but also for commercial purposes. Those ports facilitate internal trade as well as external trade in Sri Lanka. It is clear that even though Sri Lanka is a small power, the ports of Sri Lanka also uphold a channel of communication between Sri Lanka and the rest of the nations. 


\section{Numbers of Population}

The fourth condition of Mahan is 'numbers of population'. When Mahan considered numbers of the population, he argued that the influence of the population should not only be considered with the numbers of inhabitants, but more specifically with the 'number following the sea, or at least enthusiastically available for employment ship-board and for the creation of naval material' (Mahan, 1890, p.45).

According to the Department of Census and Statistics, in 2018 the total population of Sri Lanka is 21.67 million. The labour force, which is the economically active population, rose by 204,252 to 8.592 million in 2019 from 8.388 million as reported in 2018, recording a growth of 2.4 percent (Central Bank, 2019, p.150). Approximately 33 percent of Sri Lanka's population lives in coastal areas that support diverse livelihoods, from fishing to tourism to manufacturing and modern urban services (World Bank, 2017, p.2). The majority of the coastal population depends on coastal natural resources for food, livelihood, and shelter. The coastal zone accounts for 24 percent of the total land area and is home to 33 percent of the population of Sri Lanka. Sixtyfive percent of the country's urbanized areas are situated in the coastal zone, and these built-up areas are home to 45 percent of the coastal population. Overall, in Sri Lanka, the coastal zone contributes 40 percent of GDP, holds half of the built infrastructure, and is the source of 90 percent of manufacturing and fish production (World Bank, 2017, p.15).

The coastline of Sri Lanka plays a significant role in the economy of the country. In particular, the coastline contains about 70 percent of the tourist infrastructure facilities, 65 percent of the marine fish production and 62 percent of the industrial units. It is estimated that more than $44 \%$ of the National Gross Production is generated in the coastal regions of Sri Lanka (Koralagama, 2008, p.1-11).

\section{National Character}

When considering "national character", Mahan has analyzed how a nation promotes industry, trades, and whether it is willing to invest in those endeavors. As Mahan analyzes, the nation's tendency towards maritime trade influences the prioritization of state authorities in favor of the development of the navy. As per the theoretical context of Mahan, the tendency towards trade, involving necessity or the production of something to trade with, is the national characteristic most important for the development of sea power (Mahan, 1890, p.54). In a broader context, the national character as defined by Mahan is a collective term referring to the attitude and aptitude of a nation's peoples towards economic development through industrial and agricultural processes, which is inseparable from the sea. 
Among the small developing states in the world, Sri Lanka has a long history of industrialization. However, the economy of Sri Lanka is primarily one dominated by agriculture. The potential for the industrial and agricultural capacity of Sri Lanka is substantial because of its location as well as human resource management and low-cost labor force.

As a national policy, over the last two decades, the government has taken several steps to decentralize manufacturing activities from Colombo to the peripheral regions to encourage import and export trade (Dias, 1987, p.71). Moreover, the Government of Sri Lanka promotes industrialization in keeping with export and import liberalization policy. In addition to the urban level production for export expansion, Sri Lanka has introduced several policies for increasing the rural level for export purposes. It is important to mention here that commercial banks and other Sri Lanka financial institutions are financing the medium and small scale industrial and non-industrial projects. Unfortunately, since independence in 1948, some factors such as the lack of external sources and technology, imbalance/inconsistencies in foreign policy behavior, civil war, global level issues, political instability, and other domestic problems have caused significant fluctuations in the development of industrial and agricultural sectors in Sri Lanka. When compared with the other developed and developing countries in the South Asian Region, Sri Lanka has taken various steps to develop small and medium enterprises. Nonetheless, their contribution to the national economy in Sri Lanka is still low (Gamage, 2003, p.133-150). Being an island that lies near the main sea route connecting the West to the East, Sri Lanka is better placed to conduct trade interactions with other nations. However, the prevailing national character negatively affects developing sea power in Sri Lanka.

\section{The Character of the Government}

In his book, Mahan argues that the character of the government and the accompanying institutions are vital factors in determining the sea power of a state. For Mohan, the government provides direction for the growth of maritime enterprise as well as causing its success or failure in a man's life or a nation's history. Moreover, he has highlighted that a government without popular support would not be able to create a great naval power and improve sea commerce. In this context, he has suggested that the government's policy should be considered as effective, especially when it is counted with the natural inclination of citizens. Finally, he encourages the government to conform to democratic principles.

Among colonial territories which gained independence following World War II, Sri Lanka, as a 'model colony' and standard-bearer for democracy, was widely considered to have a good chance of succeeding democratically (Devotta, 2014, p.139). Since independence in 1948, Sri Lanka 
has experienced three constitutions having unusually severe political and constitutional turbulence.

The present Constitution, adopted in 1978 and amended 19 times thereafter, established the Second Democratic Republic government featuring proportional representation. Notably, the contemporary debates on constitutionalism in Sri Lanka highlights that Sri Lanka is challenged under the 1978 constitution. Therefore, there is a demand in Sri Lanka for constitutional reforms. However, the majority of conventional and modern political elite groups in Sri Lanka are more interested in gaining political power rather than democratic political reforms. Moreover, the emergence of the Tamil separatists terrorism and the JVP insurrections still remain as the main forces of mass resistance to the character of the government after its independence. It is important that the political maturity of Sri Lankan society and the long tradition of democracy in Sri Lanka are not underestimated (Amarasuriya, 2006, p.23). In a broader context, the constitutional turbulence, elite politics as well as violent resistance against the Sri Lankan state by the LTTE and the JVP has resulted in shaping the existing character of the government. As discussed above, the existing character of the government has brought up more serious challenges and obstacles for developing the sea power of Sri Lanka.

\section{Conclusion}

Historically, the marine area of Sri Lanka makes important contributions to the economic development and well-being of Sri Lankans. Similarly, the geo-political location of Sri Lanka provides a usual protection for its survival. Even though Sri Lanka is a small power, its geo-strategic location at the centre of the Indian Ocean and the maritime silk route between China and Europe facilitate cross-border trade and commerce. Further, it provides a home to major sea routes connecting Africa, the Middle East and East Asia with Europe and the Americas. Specifically, the marine area of Sri Lanka has particular geopolitical importance due to its location in between the Strait of Hormuz and the Strait of Malacca which are the most important transit zones in the world.

In addition, the marine area of Sri Lanka is supposed to hold the world's oil reserves and natural gas reserves. Thus the present comprehensive analysis have shown that the existing triangular strategic competition in term of geo-strategical importance of the marine are of Sri Lanka in the Indian Ocean has created significant implications for Sri Lanka. With China's emergence as the most important trading partner of the marine area of Sri Lanka since 2009, Sri Lanka faces numerous maritime security challenges after the Cold War. In addition to traditional security issues, further, the marine area of Sri Lanka has become a source of non-traditional security issues such 
as piracy, climate change, illegal maritime terrorism, unreported and unregulated (IUU) fishing, illegal immigration, and smuggling of arms and drugs as well.

Being a small power and a geo-strategically significant island, the safety defensive of the marine area of Sri Lanka is essential for enhancing both aspects of national security, namely state security as well as human security. In this regard, protecting, controlling, and managing living and non-living natural resources, coastal erosion, trade routes, commerce, safety traveling, and physical and visual access to the ocean of Sri Lanka have become significant approaches to address the prevailing traditional and non-traditional maritime security issues and challenges. As per the following diagram, mapping the sea power of Sri Lanka very closely interacts with different elements.

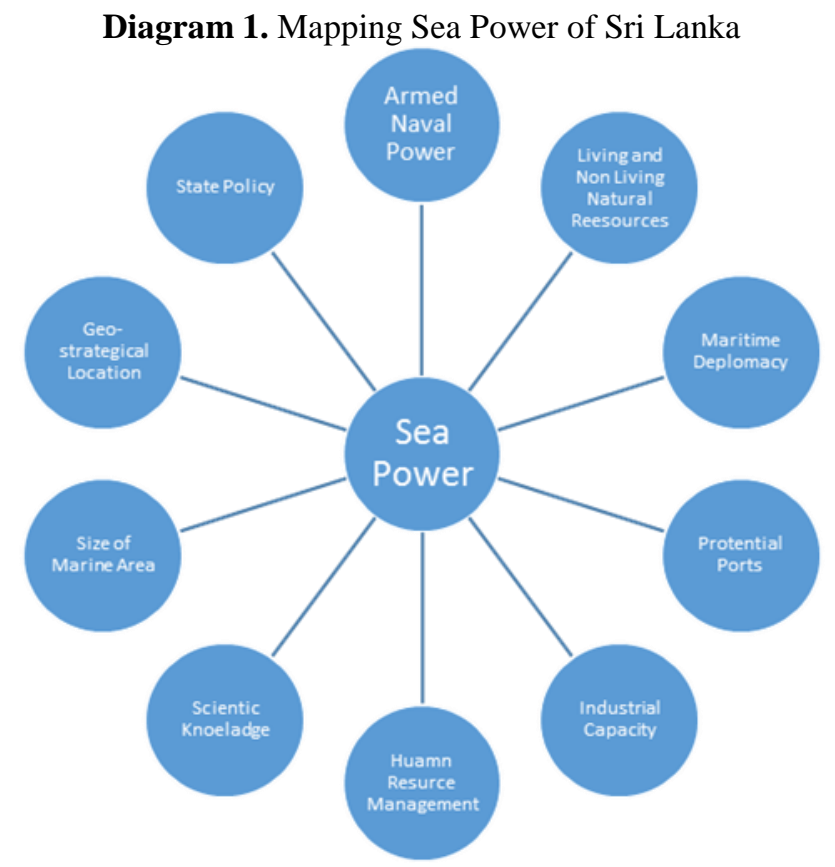

Even big or small power, the maritime doctrine, as Mahan pointed out, is also an integral component of national power in general and sea power in particular. Since its independence, Sri Lanka has not focused much attention on developing a proper maritime doctrine that covers its geo-strategical significance. In his analysis, Mahan highlights that a powerful navy is significant not only for protection in the time of war but also for the continuation of peaceful shipping (Mahan, 1890, p.27). Some of his arguments are fundamental because generating armed naval power is essential for minimizing the prevailing and emerging traditional and non-traditional maritime security issues and challenges faced by Sri Lanka. 


\section{Policy Recommendations}

Since Sri Lanka is a geo-strategical location and an emerging hub of the Indian Ocean, a very sophisticated naval power is needed to safeguard the sovereignty of its marine area, including the provision of security and safety for nearly 900 commercial ships crossing its marine area daily peacefully. In this regard, Dubai and Singapore are typical examples. Therefore, the Government of Sri Lanka should develop the strength of ports by providing more attention to naval expansion, including the navy and Sri Lanka Coastal Guard in order to enhance both the national security interest and objectives of Sri Lanka.

In addition to the navy's strength, Sri Lanka needs a much better focus for developing a trade and commerce hub on the Indian Ocean between Singapore, Mumbai, Aden, and Dubai. It will provide an opportunity for Sri Lanka's ports to enhance the accommodation of nearly 50 percent of global container traffic and nearly 70 percent of the seaborne oil that passes through the Indian Ocean. At the same time, Sri Lanka should develop its industrial capacity, scientific knowledge, and human resource management. Furthermore, improving Sri Lanka's maritime diplomatic relations with other potential nations is another important aspect for enhancing the national interests from its geo-strategical significance. Furthermore, it is essential to note that the maritime diplomatic practices of Sri Lanka, combining safety and security community developments, can be an approach to minimize the maritime challenges of the $21^{\text {st }}$ century. Broadly, the Government of Sri Lanka should have a long-term and short-term agenda for the protection, conservation, extraction, and consumption of sea-born living and non-living natural resources for enhancing its sea power.

\section{References:}

1. Akzin Benzamin (1964). State and Nation, London: West View.

2. Amarasuriya Harini (2016). 'Elite Politics and Dissent in Sri Lanka', ISAS Working Papers, Singapore: National University of Singapore.

3. Ayoob Mohammed (1995). The Third World Security Predicament, Boulder: Lynne Rienner.

4. Azar Edward, E. \& Chung-in Moon (eds.) (1988). National security in the Third World: The Management of Internal And External Threats, Hants: Edward Elgar.

5. Bhargave Pradeep (1987). Political Economy of Sri Lanka, New Delhi: Navrang.

6. Brass Paul (ed) (1985). Ethnic Groups and the State, London: No. Publisher.

7. Briguglio Lino \& Eliawony Kisanga (2004). Economic Vulnerability and Resilience of Small States, London: Commonwealth Secretariat. 
8. Bull Hedley (1984). Intervention in World Politics, New York: Oxford University Press.

9. Bush Kenneth, W. (2003). The Intra-Group Dimensions of Ethnic Conflict in Sri Lanka: Learning to Read between the Lines," New York: Macmillan.

10. Buzan Barry (1988). "People, States and Fear: The National Security Problem in the Third World" in Edward E. Azar and Chung-in Moon (eds.), National Security in the Third World: The Management of Internal and External Threats, England: Hants.

11. Buzan Barry (1991). People, States and Fear: The National Security Problem in International Relations, Boulder: Lynne Rienner.

12. Carrai Maria Adele (not available). 'China's Malleable Sovereignty along the Belt and Road Initiative: The Case of The 99-Year Chinese Lease of Hambantota Port', International Law and Politics, Vol. 51: pp. 1061-1099.

13. Corbett Sir Julian (1988). Some Principles of Maritime Strategy, with an introduction of Eric Grove, Annapolis: Naval Institute Press, first published 1911.

14. Crowl Phillip, A. (1986). 'Alfred Mahan: the naval historian'. In: Peter Paret (ed.), Makers of Modern Strategy from Machiavelli to the Nuclear Age. Nova Jersey: Princeton University Press. pp. 444-480.

15. De Silva, K. M. (1981). History of Sri Lanka, Berkeley: University of California Press.

16. De Silva, K. M. (1996). Regional Powers \& Small State Security: India \& Sri Lanka, New Delhi: Vikas Publishing.

17. Devotta Neil (2014). 'Parties, political decay, and democratic regression in Sri Lanka', Commonwealth \& Comparative Politics, 52:1, pp. 139-165.

18. Dias Sriyani (1987). Industrialisation Strategy in Sri Lanka - Recent Changes in Policy and Promotional Measures', Sri Lanka J. S. S, Vol.10 (1 \& 2).

19. Dixit, J. N. (1998). Assignment Colombo, Colombo: Vijitha Yapa Books.

20. Gamage Aruna, S. (2003). 'Small and Medium Enterprise Development in Sri Lanka: A Review’, 名城論叢, pp. 133-150.

21. Garver John, W. (2001). Protracted Contest: Sino-Indian Rivalry in the Twentieth Century, University of Washington Press: Seattle and London.

22. Germond, B. (2015). Sea power and International Relations. In: The Maritime Dimension of European Security: Palgrave Studies in European Union Politics. Palgrave Macmillan, London. 
23. Gorshkov, SG. (1979). The Sea Power of the State, Oxford: Pergamon Press.

24. Gray Collin, S. \& Roger Barnett, W. (1989). Sea Power and Strategy, Maryland: Naval Institute Press.

25. Harding Richard (1999). Sea power and Naval Warfare, 1650-1830, London: University College Press.

26. Hunt Barry, D. (1989). 'The Strategic Thought of Sir Julian S. Corbett', in John B. Hattendorf Robert S. Jordan (eds), Maritime Strategy and the Balance of Power, Palgrave Macmillan, London, pp 110-135.

27. Jayasekera, P. V. J. (1992). Security Dilemma of a Small State, Part One, Sri Lanka in the South Asian Context, New Delhi: South Asian Publishers.

28. Joseph Leslie (not available). 'NATIONAL REPORT OF SRI LANKA on the Formulation of a Trans boundary Diagnostic Analysis and Strategic Action Plan for the Bay of Bengal Large Marine Ecosystem Programme', p. 19, [Online: web], Accessed on 12/09/2020, URL:

https://www.boblme.org/documentRepository/Nat_Sri_Lanka.pdf

29. Koburger Charles, W. Jr. (1990). Narrow Seas, Small Navies and Fat Merchantmen, New York: Praeger.

30. Koralagama Dilanthi (2008). 'Community Perception Towards A Set Back Area: A Case Study in Galle District, Sri Lanka', IIFET Vietnam Proceedings, [Online: web], Accessed on 16/12/2020, https://core.ac.uk/download/pdf/10197728.pdf?repositoryId=197

31. Mahan, A.T. (1890). The Influence of Sea Power on History, 16601783, Boston: Brown and Company, [Online: web], Accessed on 12/09/2020, URL: http://www.gutenberg.org/files/13529/13529h/13529-h.htm Release Date: September 26, 2004 [eBook \#13529], most recently updated: November 19, 2007

32. Mathew, K.S. (1990). Studies in Maritime History, Pondicherry: Pondicherry University

33. Pernetta, J.C. (ed.) (1993). 'Marine Protected Area Needs in the South Asian Seas Region', Sri Lanka, Marine Conservation and Development Report, Volume 5, Switzerland: IUCN, Gland.

34. Silva Antonio Ruy de Almeida (2017). 'The Enabling Power of the Oceans', Contexto Internacional, vol. 39(2), pp. 237-243.

35. Singh Dupinder (1994). Indian Ocean and Regional Security, India: B.C. Publications

36. Subrahmnyam, A. (1970). 'The Challenge of the Seventies to India's security', in India Quarterly, April-June. 
37. Tan Andrew, T. H. (ed.) (2011). The Politics of Maritime Power: A Survey, London: Routledge.

38. Tangredi Sam, J. (ed.) (2002). Globalization and Maritime Power, Washington, D.C.: National Defense University Press.

39. Tangredi Sam, J. (ed.) (2002). Globalization and Maritime Power, Washington, D.C.: National Defense University Press.

40. Till Geoffrey (1982). Maritime Strategy and the Nuclear Age, London: Macmillan.

41. Wescott Allan (1999). Mahan on Naval Warfare, Mineola NY: Dover Publications.

42. Wijesinha Anushka (2016). "Can Sri Lanka Leverage Its Location as Indian Ocean Hub?" The Diplomat.

43. Annual Report of Central Bank. (2019). Colombo: Central Bank of Sri Lanka.

44. Sri Lanka: Managing Coastal Natural Wealth (2007). The World Bank: Washington DC. 